\title{
Balancing science and public policy in Pakistan's COVID-19 response
}

Zulfiqar A. Bhutta, ${ }^{1,2}$ Faisal Sultan, ${ }^{3}$ Aamer Ikram, ${ }^{4}$ Adil Haider, ${ }^{5}$ Assad Hafeez ${ }^{6}$ and Muhammad Islam ${ }^{2}$

${ }^{1}$ Institute for Global Health \& Development, The Aga Khan University, South-Central Asia, East Africa \& United Kingdom, Karachi, Pakistan (Correspondence to: Z. Bhutta: zulfiqar.bhutta@aku.edu). ${ }^{2}$ Centre for Global Child Health, the Hospital for Sick Children, Toronto, Canada. 3Shaukat Khanum Memorial Hospital \& Research Centre, Lahore, Pakistan. ${ }^{4}$ The National Institute of Health, Islamabad, Pakistan. ${ }^{5}$ The Aga Khan University Medical College \& Hospital, Karachi, Pakistan. ${ }^{6}$ Health Services Academy, Islamabad, Pakistan.

\begin{abstract}
Background: Coronavirus disease 2019 (COVID-19) has affected the world in an unprecedented manner and South Asian countries were among the first to experience imported cases. Pakistan's response to COVID-19 has been under scrutiny for its granularity, reach and impact.

Aims: to evaluate objectively the chronology and depth of the response to COVID-19 in Pakistan.

Methods: We evaluated available national and subnational epidemiological and burden information on COVID-19 cases and deaths in Pakistan, including projection models available to the Government at an early stage of the pandemic.

Results: Pakistan, with a population of 215 million and considerable geographic diversity, experienced case introduction from pilgrims returning from the Islamic Republic of Iran, followed by widespread community transmission. The National Command and Operations Centre, established through civilian and military partnership, was critical in fast tracking logistics, information gathering, real-time reporting and smart lockdowns, coupled with a massive cash support programme targeting the poorest sections of society. Cases peaked in June 2020 but the health system was able to cope with the excess workload. Since then, although testing rates remain low (> 300000 cases confirmed to date), case fatality rates have stabilized, and with 6300 deaths, Pakistan seems to have flattened the COVID-19 curve.
\end{abstract}

Conclusion: Despite notable successes in controlling the pandemic, several weaknesses remain and there are risks of rebound as the economy and educational systems reopen. There is continued need for strong technical and programmatic oversight, linked to civic society engagement and working with religious scholars to ensure nonpharmacological intervention compliance.

Keywords: COVID-19, disease surveillance, mitigation strategies, nonpharmacological interventions, Pakistan

Citation: Bhutta Z; Sultan F; Ikram A; Haider A; Hafeez A; Islam M. Balancing science and public policy in Pakistan's COVID-19 response. East Mediterr Health J. 2021;27(8):798-805. https://doi.org/10.26719/emhj.21.016

Received: 28/09/20; accepted: 28/01/21

Copyright (C) World Health Organization (WHO) 2021. Open Access. Some rights reserved. This work is available under the CC BY-NC-SA 3.o IGO license (https://creativecommons.org/licenses/by-nc-sa/3.o/igo)

\section{Introduction}

The world has witnessed an 18 month period like no other. From the early reports of a new disease caused by a possible coronavirus, subsequently confirmed to be severe acute respiratory syndrome coronavirus (SARSCoV)-2, the outbreak became an epidemic with clear global risks. The resultant infection, called coronavirus disease 2019 (COVID-19), was declared a global pandemic on 11 March 2020 (1). Over the last 18 months, COVID-19 has spread across the globe and led to $>196$ million infections and 4.2 million deaths (2). The disease continues to baffle epidemiologists and public health professionals across much of the developed world, with huge impacts on the economic, trade, commercial and public health outcomes. Low- and middle-income countries (LMICs) are no exception, and many have also suffered outbreaks with huge loss of life and economic disruptions.

\section{Early disease introduction and epidemiology in Pakistan}

Pakistan experienced early introduction of COVID-19 in February 2020. This was not surprising given its prox- imity to China, where the outbreak originated, and the Islamic Republic of Iran, one of the first major outbreak epicentres outside Europe. While the initial focus was on inbound travellers from China, this was rapidly readjusted towards suspected cases among pilgrims returning by road from holy sites in the Islamic Republic of Iran. Unlike structured airport entries, the Iranian border crossing in the remote location of Taftan in Balochistan Province meant that initial arrangements were inadequate and makeshift facilities for screening and quarantine had to be established. The disease quickly spread to all metropolitan centres and districts of Pakistan, although several rural districts of Balochistan and Southern Khyber Pakhtunkhwa Province had comparatively lower reported numbers of cases and negligible reported deaths. However, this was likely related to limited testing at population level (Figure 1).

\section{What guided national policy and early multisectoral responses?}

Health sector limitations in developing a comprehensive strategy for response became evident soon after identifi- 


\section{Figure 1 Coronavirus disease 2019 (COVID-19) morbidity and mortality distribution in Pakistan in March-September 2020}

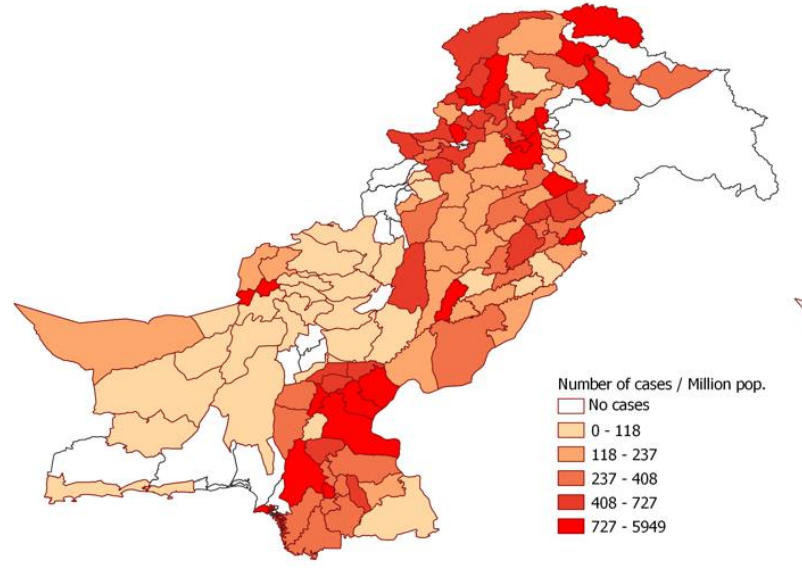

cation of the first group of cases in Sindh among returning pilgrims from holy sites in the Islamic Republic of Iran on 26 February 2020, as there were negligible public health laboratories with the capacity and standardized protocols for real-time polymerase chain reaction (PCR) diagnosis of SARS-CoV-2 infections. These needed to be established including a mobile testing laboratory at remote Taftan, alongside quarantine facilities.

As the pandemic and its attendant challenges expanded into nonhealth domains, the initial response, mainly centred within the Federal Ministry of National Health Services, Regulation \& Coordination (MoNHSRC), had to be completely redesigned. Formation of the National Coordinating Council (NCC) on 13 March 2020, headed by the Prime Minister with representatives from all key ministries including health, was a key early step, followed soon by the establishment of a National Command and Operations Center (NCOC) on 27 March 2020. The NCOC was the implementation arm of the

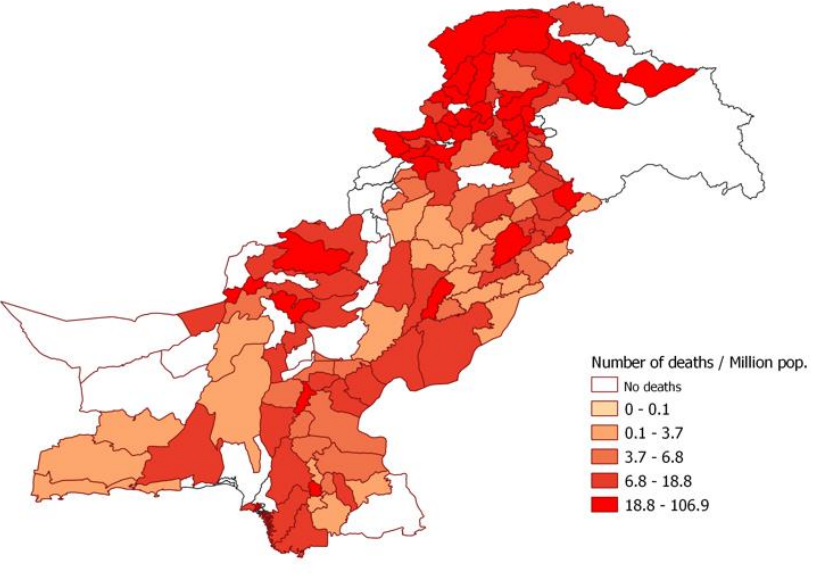

NCC for coordination across multiple provinces and jurisdictions, as well as between entities of the Federal Government (3). Other notable actions, despite limited resources, were the inclusion of the National Disaster Management Authority (NDMA) for emergency procurement and deployment of a wide range of resources by the Federal and Provincial Governments.

There was little to guide the national response in the initial stages, beyond the broad early guidance of the World Health Organization and the response emerging from countries in the extreme grip of the pandemic (January to February 2020). These included China, which after an initial period of confusion and limited information, imposed a strict lockdown despite the Chinese New Year, to restrict movement of its population (4). With the rapidly changing initial responses from European and North American countries, the Pakistan Government imposed a series of early nonpharmacological interventions (NPIs), including closure of educational

\section{Figure 2 Epidemiological curve and nonpharmacological interventions in Pakistan (February-September 2020)}

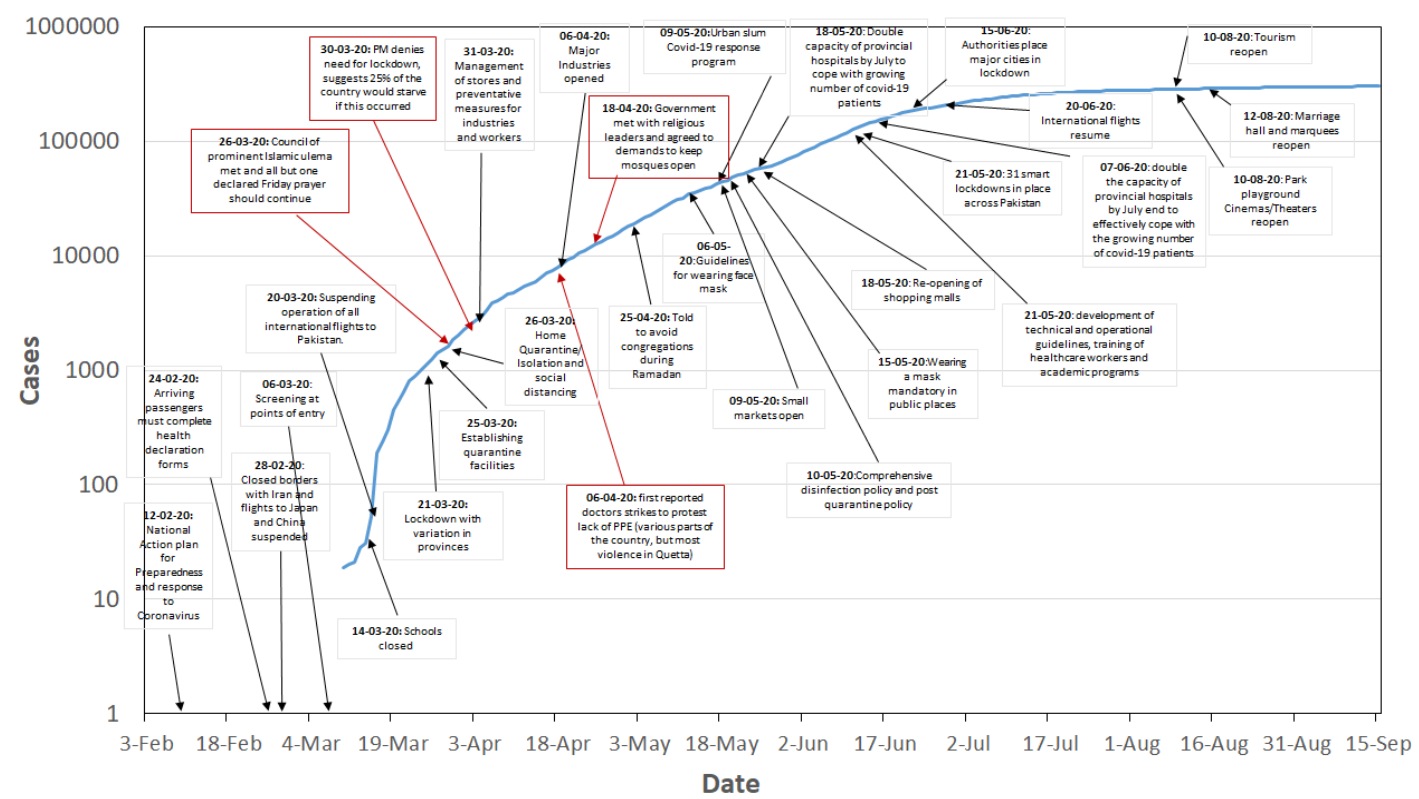


institutions, bans on large gatherings like weddings, and closure of some nonessential businesses. Extension to a full lockdown in the largest city of Karachi followed on 23 March 2020, and a day later in other major metropolitan areas. These were met by various challenges at different stages, given planned religious mass gatherings and traditional practices in the month of Ramadhan (Figure 2). Notwithstanding these considerations, strict implementation of movement restrictions and business closures played a major role in flattening the incidence curve, and preparing the health sector for the predictable surge of cases.

Capacity and equipment for molecular diagnostics in public sector laboratories in Pakistan were limited. From the initial 4 laboratory testing sites in the public sector with a maximum daily capacity of 400 PCR tests, stemmed several testing sites across the country, established by the Federal Government under the supervision of Pakistan's National Institute of Health (NIH) by the end of February. The Federal and Provincial Governments established expert committees to address COVID response, guidelines and regulations. The foci of these oversight groups were development of standard operating procedures for case detection (establishing testing systems and staff training), and guideline development for infection control in various settings as well as clinical care of patients with COVID-19. A small think tank was set up at the federal level for coordinating efforts and streamlining procurements, imports and distribution of testing kits and equipment, staff training and personal protective equipment (PPE). As Figure 3 indicates, notwithstanding considerable regional differences in rates of testing, overall numbers of confirmed cases per day climbed to a maximum of around $6000-7000$ by mid-June and decreased to the current daily average of $<500$. The number of COVID-19 related deaths, which is based on a standardized reporting system from $>500$ hospitals across the country, has decreased consistently and steadily.

\section{Local epidemiology and policy guidance}

Lack of capacity and paucity of national and provincial public health institutions have affected the rapidity of obtaining relevant population-based information from research. The COVID-19 oversight committees established at the federal and provincial level focused initially on logistics, and only began investing in data systems by the end of March 2020, reporting directly to the NCOC and publishing situational analyses on a daily basis on a public MoNHSRC COVID-19 information portal (5). This became a vital link for monitoring and trend analysis.

A crucial element was enabling systematic inflow of testing data from a constantly increasing number of laboratories across the provinces and from public, private and nonprofit sectors. In a remarkable redeployment of resources, the existing reporting network and database for polio surveillance was used to fast track the process, and electronic interfaces were created to ensure rapid and accurate data flow. It was quickly recognized that there was little capacity within the existing health system infrastructure, even in large provincial capitals, to cope with the anticipated rise in critically ill patients. Hence, an essential objective of the initial rapid response strategy was to flatten the epidemiological disease curve to allow enough time to build systems' capacity. While there were around 2000 intensive care beds in the country initially, few had the capacity to take care of COVID patients (Table 1). Several health facilities had to be revamped and equipped for functionality. The NCOC and NDMA played a crucial role in fast tracking procurement and local production of key commodities such as PPE and hand sanitizers. Local manufacturing of ventilators was initiated and by June 2020, Pakistan became largely selfreliant on the COVID-19 supply chain and logistics.

\section{Data for decision making}

Establishing a central, accurate data repository was key to evidence-informed decision-making, which was facil-

Figure 3 Trends in confirmed cases and coronavirus disease 2019 (COVID-19) deaths in Pakistan

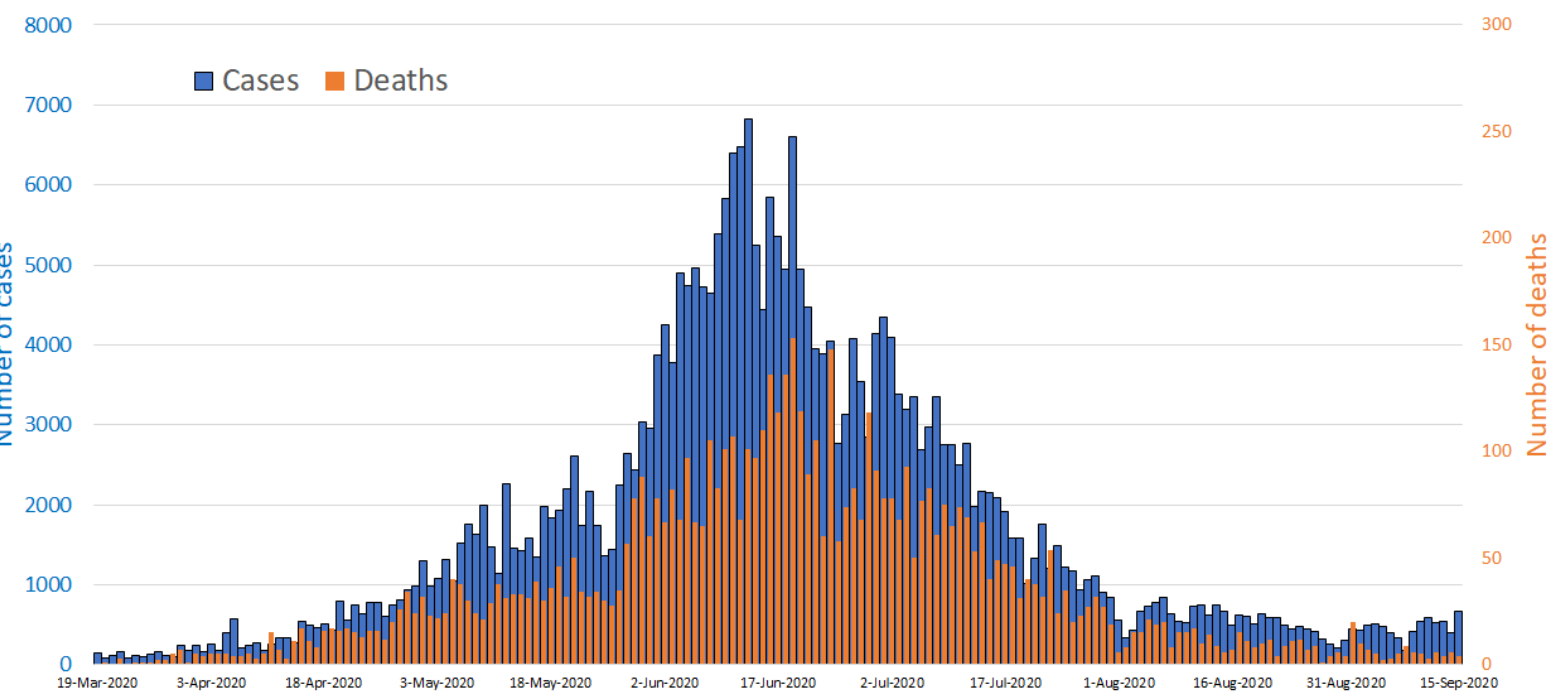




\begin{tabular}{|c|c|c|c|c|c|c|c|}
\hline$\Xi$ & $\begin{array}{l}\stackrel{\infty}{m} \\
\stackrel{m}{f} \\
\stackrel{f}{2}\end{array}$ & $\begin{array}{l}\text { ồ } \\
\stackrel{n}{m} \\
m\end{array}$ & 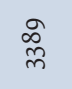 & $\stackrel{\hat{m}}{m}$ & & $\stackrel{\stackrel{n}{\approx}}{\kappa}$ & $\begin{array}{l}\stackrel{2}{2} \\
\stackrel{1}{\Lambda}\end{array}$ \\
\hline$\stackrel{\circ}{\rightrightarrows}$ & 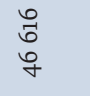 & \begin{tabular}{l} 
i \\
N \\
\multirow{2}{*}{}
\end{tabular} & 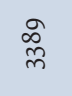 & & $\begin{array}{l}\text { ¿ } \\
8 \\
\circ \\
\text { in }\end{array}$ & $\stackrel{\stackrel{n}{n}}{\sim}$ & 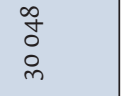 \\
\hline & 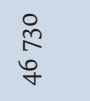 & $\begin{array}{l}\text { } \\
\alpha \\
\text { స్}\end{array}$ & $\stackrel{\substack{m \\
m}}{m}$ & ঃे & $\begin{array}{l}\stackrel{8}{\circ} \\
\dot{7}\end{array}$ & $\stackrel{\sim}{\sim}$ & \begin{tabular}{l}
$\infty$ \\
\multirow{1}{*}{} \\
0 \\
0
\end{tabular} \\
\hline ब & $\begin{array}{l}\stackrel{ }{N} \\
\stackrel{m}{+}\end{array}$ & $\underset{\vec{N}}{\stackrel{g}{+}}$ & 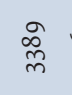 & $\begin{array}{l}\overrightarrow{0} \\
\dot{m}\end{array}$ & 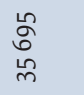 & $\stackrel{m}{\approx}$ & 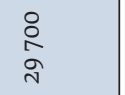 \\
\hline$\infty$ & $\begin{array}{l}\text { Dे } \\
\text { o } \\
\stackrel{m}{m}\end{array}$ & $\begin{array}{l}\text { Ln } \\
\infty \\
0 \\
\stackrel{N}{\text { N }}\end{array}$ & ঃ & ণ্̀ & $\begin{array}{l}0 \\
\text { వ } \\
\infty \\
\text { న }\end{array}$ & \begin{tabular}{c} 
\} $\\
{\infty}$ & $\begin{array}{l}\stackrel{0}{\sigma} \\
\stackrel{\sim}{N}\end{array}$ \\
\hline 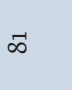 & $\begin{array}{l}\stackrel{8}{\circ} \\
\stackrel{1}{0} \\
\stackrel{m}{n}\end{array}$ & $\begin{array}{l}\text { O } \\
\text { o } \\
\text { I }\end{array}$ & ஃ্ণ & $\begin{array}{l}\hat{D} \\
\text { iै }\end{array}$ & $\begin{array}{l}\text { ڤ } \\
\text { ने }\end{array}$ & 곤 & 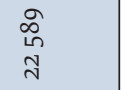 \\
\hline ה & $\begin{array}{l}0 \\
0 \\
0 \\
9 \\
9\end{array}$ & $\begin{array}{l}\widehat{\hat{0}} \\
\pm \\
\end{array}$ & $\begin{array}{l}\circ \\
\stackrel{\circ}{\circ}\end{array}$ & 总 & $\begin{array}{l}\stackrel{0}{0} \\
\stackrel{0}{\circ} \\
0\end{array}$ & $\stackrel{\sim}{\sim}$ & $\begin{array}{l}n \\
\infty \\
0 \\
\vec{\lambda}\end{array}$ \\
\hline ถે & $\begin{array}{l}\infty \\
\stackrel{7}{ \pm} \\
\underset{J}{*}\end{array}$ & $\underset{\infty}{\stackrel{d}{+}}$ & 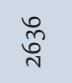 & 节 & $\begin{array}{l}\hat{\lambda} \\
\stackrel{-}{\circ}\end{array}$ & $\hat{}$ & $\begin{array}{l}\stackrel{+}{+} \\
\stackrel{+}{+}\end{array}$ \\
\hline $\overrightarrow{7}$ & 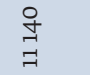 & $\begin{array}{l}\stackrel{0}{\infty} \\
\underset{m}{m}\end{array}$ & 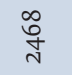 & ঙัフ & \begin{tabular}{l}
$\infty$ \\
\multirow{2}{\sigma}{}
\end{tabular} & $\begin{array}{l}\infty \\
\infty \\
\infty\end{array}$ & 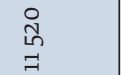 \\
\hline 9 & $\begin{array}{l}\text { స } \\
\text { ట్ర }\end{array}$ & $\stackrel{\llcorner}{\kappa}$ & $\underset{N}{F}$ & $\underset{\sim}{\stackrel{\sim}{\sim}}$ & ڤ્े & $\underset{f}{g}$ & $\stackrel{\stackrel{\aleph}{N}}{\stackrel{n}{n}}$ \\
\hline$\exists$ & 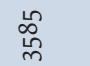 & 衤 & 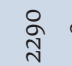 & $\underset{\infty}{\infty}$ & ڤે & 1 & 1 \\
\hline ఠે & 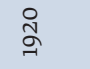 & 1 & ஷ্ণ & స్త & 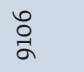 & 1 & 1 \\
\hline 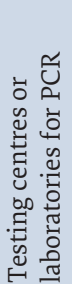 & 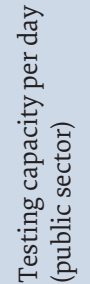 & 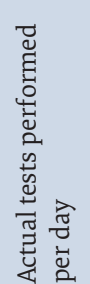 & 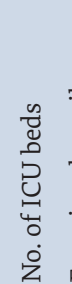 & 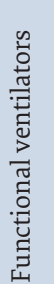 & 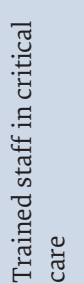 & 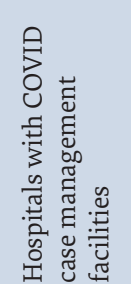 & 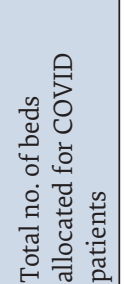 \\
\hline
\end{tabular}
\end{tabular}

itated by the Digital Pakistan initiative with a data synthesis system, and the launch of the Pak Nigehban App (6) to track and localize resources, especially the availability of intensive care unit (ICU) beds and ventilators.

The Government used 3 different forecasting models for short- and medium-term decision making but these were not put in the public space. Alternative models, including those indicating dynamic disease projection profiles and duration, were produced by groups at the University of Toronto (7), Imperial College London (8) and the Institute of Health Metrics \& Evaluation in Seattle (9), and were disparate in their predicted trends (Figure 4). The modelling exercise collectively guided the planning and decision-making at the federal and provincial level despite a gap in quality data collection systems; however, a learning curve was observed on both the demand and supply side of such information. It is unclear if any of these models drove policy as none were put up for public debate and scrutiny by the national scientific community. In fact, given limited testing and rudimentary data on response systems, many of these projections were met with scepticism or largely ignored in favour of real-time reporting of admissions and deaths. Given widespread scepticism at different stages as to the exact direction and severity of the pandemic in Pakistan, and widespread disagreements among various sections of society, especially the electronic and print media, medical professional bodies, mainstream political parties and religious scholars, it took time to develop a national consensus on approaches and solutions. In hindsight a national conference and consultative process with civic society could have avoided much acrimony and led to a common nonpartisan strategy (10).

\section{What went well?}

Notwithstanding the above and resource constraints, the Pakistan Government moved with alacrity once the scale of the disaster in other countries became apparent. Despite the limited role that the federal MoNHSRC has following the devolution of health services to the provinces in 2011 (11), the multi-stakeholder response that it had was able to spearhead and support the national COVID-19 response. It played a key role in the NCOC which was chaired by the Federal Minister for Planning \& Development. The NIH rose to the task of training technicians, procuring testing equipment and boosting capacities across Pakistan, and daily testing capacity was enhanced from < 2000 tests daily to a capacity of > 50000 across the public sector testing sites by August 2020. The NCOC resolved the issues of logistics, supplies and procurements as a national emergency through the NDMA ranging from vital PPE, oxygen supply systems and establishment of COVID-19 care and treatment centres across the country. Pakistan faced a critical shortage of human resources with $<9500$ trained professionals in critical care at the outset of the pandemic. Virtual training and skills development programmes for staff were launched by the Aga Khan University, Health Services 
Figure 4 Projections of coronavirus disease 2019 (COVID-19) deaths in Pakistan (various models as of June 2020)

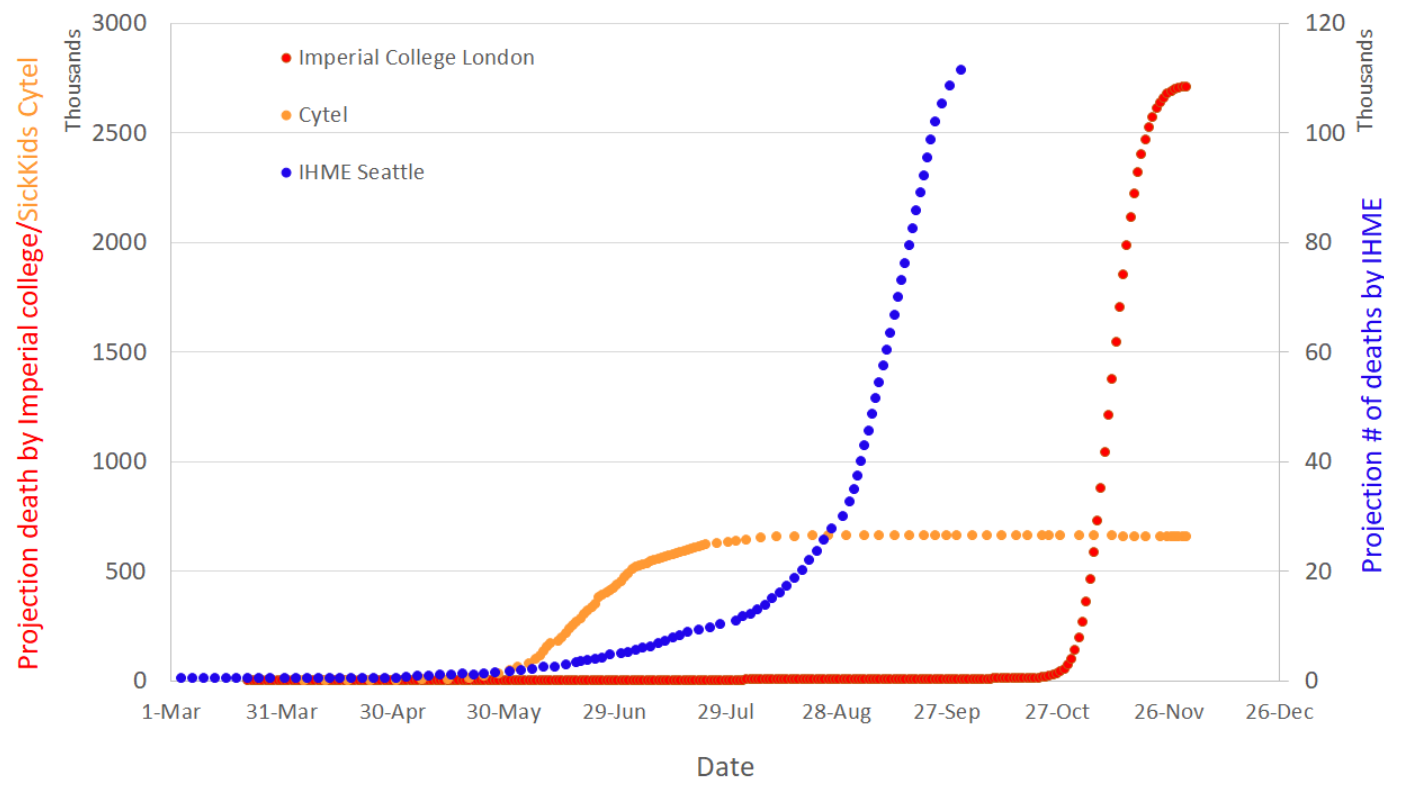

Academy and NIH partnership (12), which has trained > 50000 staff members to-date.

A remarkable achievement was the establishment of a central reporting system for data at national and provincial levels with the ability to provide district-level estimates. This was real-time reporting and publicly available, in contrast with many other governments in South Asia. The establishment of a data flow system made both central and provincial level response planning possible. This was supported in due course by the innovative approach to contact tracing and identification of hotspots with local response; the so-called smart lockdowns (13). Deliberate efforts were also made to inform the public about the virus and to reinforce necessary precautions. All mobile phones in the country replayed short messages related to COVID-19 prevention strategies prior to connecting any phone call as a public service, and numerous social media campaigns were conducted at a variety of public and private levels.

To spur private sector investments, the State Bank of Pakistan Refinance Facility for Combating COVID-19 (SBP-RFCC) provided loans at $<3 \%$ interest to hospitals and medical centres. Funds were meant for COVIDrelated expenses, from expanding/upgrading facilities to purchasing equipment such as ventilators or enhanced PPE. More than 6 billion Pakistani rupees (PKR) were disbursed to 35 hospitals, adding 13 brand new wards, 1112 additional beds and $>350$ ventilators.

Pakistan also launched a robust response to the secondary effects of the sudden lockdown and loss of income for daily wage earners. A key intervention was the launch of cash disbursement through an existing social safety net Ehsaas (which means percipience). The programme targets female heads of households with disbursal of PKR 12000 (US\$ 75) allocated for each of the 12 million potential beneficiaries at risk of extreme financial hardship and food insecurity (14). The rapid institution of these response strategies as well as considerable private philanthropy and charitable support were some of the main reasons that Pakistan did not witness the tragic exodus of migrant workers and slum dwellers from the megacities seen elsewhere.

Only time will tell the exact impact on education systems and learning across the large network of public sector schools that were forced to close by the end of March. While private schools and universities were able to initiate on-line teaching, the same was not possible for $>200000$ primary, middle and secondary schools in Pakistan, supporting some 25 million students (15). The Government launched a television channel (TeleSchool) dedicated to education on 13 April 2020.

The role of the Prime Minister was notable. Early on, when restrictions and lockdowns were the mainstay of response, he spearheaded the Ehsaas programme for cash assistance, and thereafter took the decision, criticised by many as a financially risky, to reopen the economy and move to a strategy of contact tracing and smart lockdowns. This was brave and saved Pakistan from the tragic consequences of an abrupt and prolonged closure of the economy. The same decision, after much deliberation, to reopen schools and educational institutions by 15 September 2020 is reflective of actions by NCOC and the political leadership on firm risk-benefit analysis.

\section{What did not work?}

Despite the achievements listed above, there were several levels of COVID-19 response in Pakistan that could have gone better (16). The numbers of tests achieved at population level remained a fraction of the desirable numbers, with considerable diversity across the country. The numbers tested in Islamabad Capital Territories were higher (124888 tests per million population) than those 
achieved in the provinces, especially Baluchistan (5955 tests per million population) and Khyber Pakhtunkhwa (7271 tests per million population), and the latter numbers appear to have gone down further in recent weeks. As of 30 July 2021, documented COVID-19 deaths in Pakistan are around 23209 overall ( 1 021000 confirmed cases), these likely underestimate the true picture given the testing level. However, it is unlikely that large-scale excess population mortality has been missed, given that burials are universal and with the limited numbers of burial sites across the country, any excess would have been evident. This was also queried in the larger cities with no evidence of excess deaths in comparable time periods.

With some disagreements on the nature of response and strictness of the lockdown, mixed messages led to unnecessary acrimony and discord, and polarization of opinions between political parties. This compounded confusion at the level of civic society with large-scale breakdown of physical distancing by the end of Ramadhan (late May 2020), a judicial order to reopen businesses (18), and the predictable upsurge in cases across the board in June.

Lack of consensus among religious scholars on the nature of restrictions and measures needed for Friday communal prayers forced some local governments to impose lockdowns covering Friday prayer times. Over time, this discord has settled and the most recent festival of Eid-ul-Adha and religious congregations during the month of Moharram did not see widespread flaunting of rules and crowding of public places. However, communication strategies and community buy-in for preventive measures such as use of face masks and physical distancing remain an issue, compounded by stigmatization of some households once identified by the smart-lockdown process. This risks engagement, reporting and hence tracking of hot spots or clusters. Premature celebration of the "victory" over COVID-19 and reduced compliance of mask use and physical distancing are major risk factors for resurgence of COVID-19, as was seen in the national Independence Day celebrations on 14 August or in some schools after reopening on 15 September 2020.

\section{What lies ahead?}

Compared with many, including neighbouring countries, Pakistan appears to have "dodged the bullet" and blunted the feared effects of COVID-19. The overall cases and fatalities are significantly lower than in its eastern and western neighbours, although within the predicted range suggested by mitigation strategies in April 2020 (7). Apart from the contribution of the Government's response detailed above, a range of factors have been cited. These include a young population (almost half are aged $<20$ years); cultural practices that restrict social networking for families outside their immediate families; and possible innate immunity with prior exposure to other coronaviruses (19). Two recent population-based serological surveys in Islamabad and Karachi suggested that between $14 \%$ and $28 \%$ of the population has antibodies to SARS-CoV-2 (AI and ZAB, personal communication 2020). However, given the unpredictability of the virus and the dreaded resurgence anticipated later this year, it is important to maintain strict compliance with preventive strategies. As has been seen in other better-resourced countries, such as the United States of America and Australia, periods of low circulation and disease burden can be followed by rapid upsurges and spread. The future in a COVID-19 era could depend on the objective analysis of the past experience and identification of possible trigger points for imposition/withdrawing of NPIs while the new cases continue to rise and fall in a population. Pakistan utilized the polio surveillance programme to monitor and track COVID-19. This must be replaced by a robust surveillance and disease warning system.

Pakistan has now reopened some of its schools, given the need to address the emerging learning gap (20). This re-entry of 53.4 million students and staff into group educational activities must be done in a careful, measured manner, with potential innovations to reduce exposure, such as shift systems for classes and almost universal use of face masks and hand hygiene. The interruption of primary healthcare services for women, children and elderly people has been massive. By most accounts, immunization rates among vulnerable children dropped precipitously as did most preventive services such as nutritional support programmes. These are being reinstituted rapidly and safely. Pakistan was able to relaunch its polio immunization campaign successfully in late July 2020 without any reports of health risks or COVID-19 exposure among vaccinators. The primary care programme with community-based lady health workers is beginning to restart its work in community education and identification of at-risk families, contributing to routine surveillance and nutritional support programmes (21).

As in any emergency response, after the "adrenaline surge" comes a period of exhaustion and the COVID-19 response has been no different. Frontline workers, managers and support staff have been working on an emergency footing for almost 18 months and by now predictable battle fatigue is setting in. Health workers have borne a disproportionate burden of exposure, infections and deaths in Pakistan but morale remains high.

It is imperative, however, that all learn to live with the virus and its unpredictability. That means a gradual reopening of the economy and learning the "new normal"; the latter could be that the virus might continue to coexist for several years and have periodic upsurges. The vaccine pipeline for COVID-19 is busy and apart from effectiveness, many questions remain as to its eventual equitable distribution and availability in LMICs. Cash and Patel (22) rightly emphasize the need for contextual responses and strategies that are fit for resource-constrained LMICs. Pakistan is an example where the national public health response was based on a blend of global guidance but with pragmatic local 
adaptation. While the Government may have taken risks in its response, the evidence to date suggests that it has worked, and with the right follow-up and care, the response could serve as an example for others to follow. For a country of 215 million people, to achieve the current stable status for an investment of under \$0.5 billion (23), is a remarkable feat but not happenstance.

Funding: Core support from the Institute for Global Health \& Development, Aga Khan University.

Competing interests: None declared.

\section{Trouver le bon équilibre entre science et politique publique dans la riposte à la COVID-19 au Pakistan}

\section{Résumé}

Contexte : La maladie à coronavirus 2019 (COVID-19) a touché le monde d'une manière sans précédent et les pays d'Asie du Sud ont été parmi les premiers à connaître des cas importés. La riposte à la COVID-19 au Pakistan a été examinée de près en raison de sa granularité, de sa portée et de son impact.

Objectifs : La présente étude vise à évaluer d'une manière objective la chronologie et la profondeur de la riposte à la COVID-19 au Pakistan.

Méthodes : Nous avons évalué les informations épidémiologiques et relatives à la charge de morbidité disponibles aux niveaux national et infranational sur les cas et les décès liés à la COVID-19 au Pakistan, y compris les modèles de projection disponibles pour le gouvernement à un stade précoce de la pandémie.

Résultats : Avec une population de 215 millions d'habitants et une diversité géographique considérable, le Pakistan a connu une introduction de cas à partir de pèlerins revenant de la République islamique d'Iran, suivie d'une large transmission communautaire. Le National Command and Operations Centre, établi par un partenariat civil et militaire, a joué un rôle crucial dans le suivi logistique rapide, la collecte des informations, l'établissement de rapports en temps réel ainsi que la mise en place des confinements efficaces, avec un programme de soutien financier ciblant les endroits les plus pauvres de la société. Le nombre de cas a atteint un niveau record en juin 2020, mais le système de santé a pu faire face à la surcharge de travail. Depuis lors, bien que les taux de dépistage restent faibles (plus de 300000 cas confirmés à ce jour), le taux de létalité s'est stabilisé et, avec 6300 décès, le Pakistan semble avoir connu un aplatissement de la courbe des cas de COVID-19.

Conclusion: Malgré les progrès notables réalisés dans la lutte contre la pandémie, plusieurs faiblesses demeurent et il existe des risques de rebond avec la réouverture de l'économie et des systèmes éducatifs. Il est toujours nécessaire d'assurer une supervision technique et programmatique solide, liée à l'engagement de la société civile et à la collaboration avec les personnalités religieuses pour garantir le respect des interventions non pharmacologiques.

$$
\begin{aligned}
& \text { التوازن بين العلم والسياسة العامة في إطار الاستجابة لكوفيد-19 في باكستان } \\
& \text { ذو الفقار بهوتا، فيصل سلطان، عامر إكر ام، عادل حيدر، أسعد حفيظ، محمد إسلام }
\end{aligned}
$$

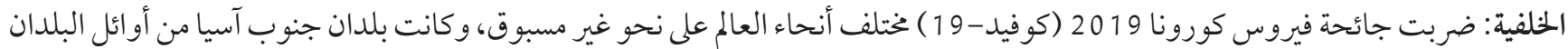

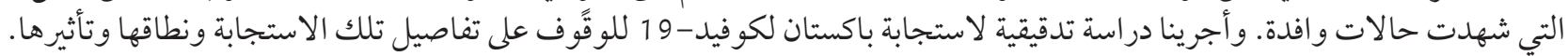

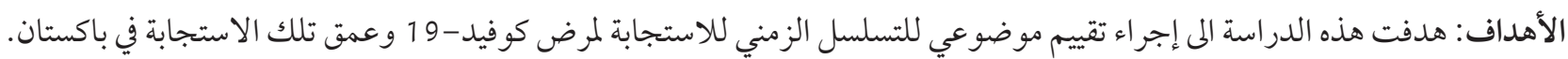

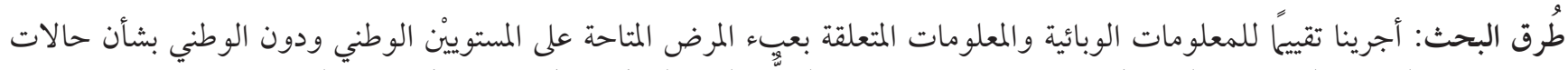

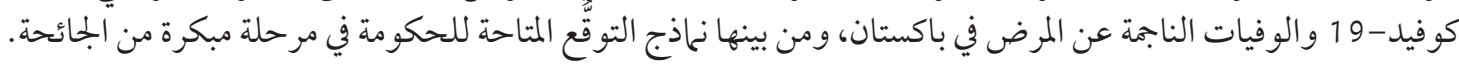

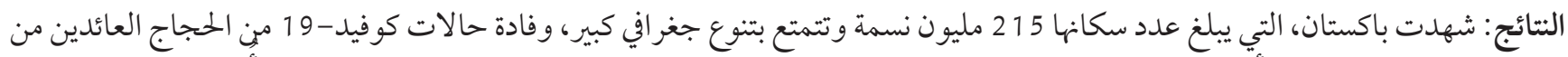

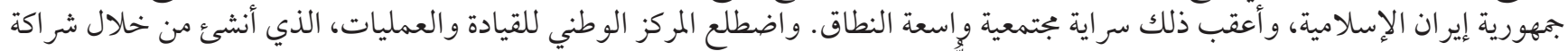

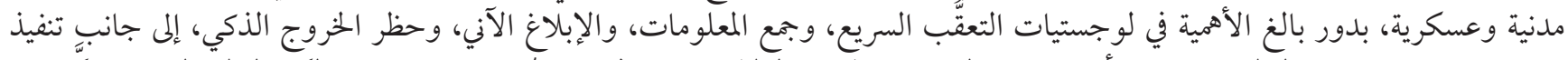

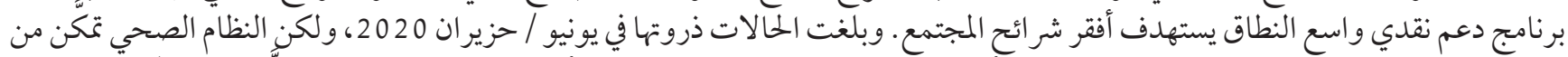

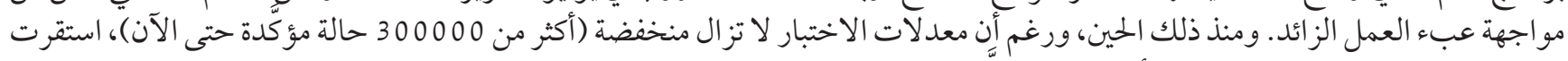

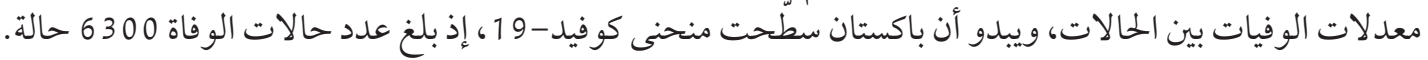

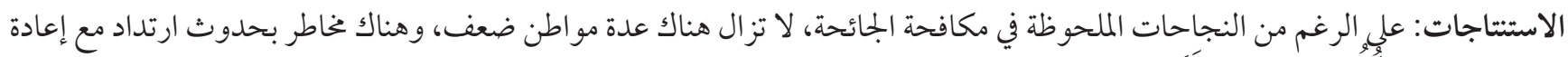

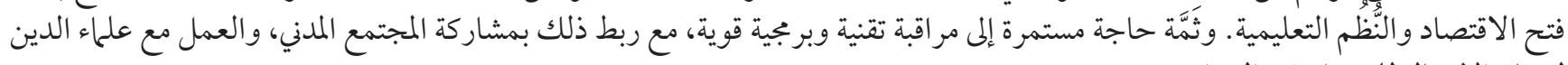
لضمان الامتثال للتدخل غير الدوائي. 


\section{References}

1. WHO Director-General's opening remarks at the media briefing on COVID-19 - 11 March 2020 [website]. Geneva: World Health Organization; 2020 (https://www.who.int/dg/speeches/detail/who-director-general-s-opening-remarks-at-the-media-briefing-on-covid-19---11-march-2020\#: :text=WHO\%20has\%20been\%20assessing\%20this,to\%20use\%20lightly\%20or\%20carelessly, accessed 24 February 2021).

2. COVID-19 Dashboard by the Center for Systems Science and Engineering (CSSE) at Johns Hopkins University (JHU) [website]. Johns Hopkins University; 2021 (https://coronavirus.jhu.edu/map.html, accessed 24 February 2021).

3. Asghar RJ. Oped. COVID19: before and after NCOC. Daily Times. 6 July 2020 (https://dailytimes.com.pk/636535/covid19-beforeand-after-ncoc/; accessed 24 February 2021).

4. Coronavirus disease 2019 (COVID-19) situation report - 44. Geneva: World Health Organization; 2020 (https://www.who.int/ docs/default-source/coronaviruse/situation-reports/20200304-sitrep-44-covid-19.pdf?sfvrsn=783b4c9d_2).

5. Pakistan case details. COVID-19 dashboard [website]. Islamabad: National Command \& Operations Center; 2020 (http://covid. gov.pk/stats/pakistan, accessed 24 February 2021).

6. NCOC launches an app named 'Pak Nigehbaan' to track the availability of ventilators [website]. Mashable Pakistan (https:// pk.mashable.com/coronavirus/3507/ncoc-launches-an-app-named-pak-nigehbaan-to-track-the-availability-of-ventilators, accessed 24 February 2021).

7. Bhutta ZA, Harari O, Park JJH, Zannat NE, Zoratti M, Churches T et al. Evaluation of effects of public health interventions on COVID-19 transmission for Pakistan; a mathematical simulation study. medRXiv (https://www.medrxiv.org/content/10.1101/202 0.04.30.20086447v1, accessed 24 February 2021).

8. Situational report for COVID-19: Pakistan , 2021-02-17 [website]. Imperial College London (https://mrc-ide.github.io/global-lmic-reports/PAK/, accessed 24 February 2021).

9. New IHME COVID-19 forecasts predict more than 40,000 deaths in Pakistan by October 1 [website]. Seattle: Institute for Health Metrics \& Evaluation; 2020 (http://www.healthdata.org/news-release/new-ihme-covid-19-forecasts-predict-more-40000-deaths-pakistan-october-1\#: :text=SEATTLE\%20\%E2\%80\%93\%20In\%20its\%20first\%20projections,COVID\%2D19\%2oby\%20October\%201, accessed 24 February 2021).

10. Mahar I. Polarization between Pakistan's federal and Sindh governments on Covid-19. Modern Diplomacy. 18 April 2020 (https:// moderndiplomacy.eu/2020/04/18/polarization-between-pakistans-federal-and-sindh-governments-on-covid-19; accessed 24 February 2021).

11. Nishtar S, Bhutta ZA, Jafar TH, Ghaffar A, Akhtar T, Bengali K, et al. Health reform in Pakistan: a call to action. Lancet. 2013 Jun 29;381(9885):2291-7. https://doi.org/10.1016/S0140-6736(13)60813-2 PMID:23684259

12. AKU commences courses on COVID-19 critical care. Aga Khan University; 2020 (https://www.aku.edu/news/Pages/News_Details.aspx?nid=NEWS-002174, accessed 24 February 2021).

13. Ibarra-Vega D. Lockdown; one, two, none, or smart. Modeling containing COVID-19 infection. A conceptual model. Science Total Environment. 2020 Aug 15;730:138917. https://doi.org/10.1016/j.scitotenv.2020.138917 PMID:32387821

14. Nishtar S. Ehsaas Emergency Cash: a digital solution to protect the vulnerable in Pakistan during the COVID-19 crisis. Government of Pakistan; 2020 (https://pass.gov.pk/Document/Downloads/EhsaasEmergencyCashReportJuly212020.pdf, accessed 24 February 2021).

15. Category wise schools in Pakistan [website]. (https://en.wikipedia.org/wiki/Category:Schools_in_Pakistan, accessed 24 February 2021).

16. Pakistan launches teleschools for e-learning. Newsweek Pakistan. 14 April 2020 (https://www.newsweekpakistan.com/pakistan-launches-teleschool-for-e-learning/; accessed 24 February 2021).

17. Bhutta ZA. Pakistan's COVID-19 response: 5 things we need to do. Daily Dawn. 15 April 2020 (https://www.dawn.com/ news/1549008; accessed 24 February 2021).

18. Afzal M. With a mix of pandemic denialism and exceptionalism, Pakistan makes a cynical bet on the coronavirus [website]. Brookings Institute; 2020 (https://www.brookings.edu/blog/order-from-chaos/2020/06/05/with-a-mix-of-pandemic-denialism-and-exceptionalism-pakistan-makes-a-cynical-bet-on-the-coronavirus/, accessed 24 February 2021).

19. Birra D, Benucci M, Landolfi L, Merchionda A, Loi G, Amato P, et al. COVID 19: a clue from innate immunity. Immunol Res. 2020 Jun;68:161-8. https://doi.org/10.1007/s12026-020-09137-5 PMID:32524333

20. COVID-19: are children able to learn through school closures? [website]. UNICEF; 2020 (https://data.unicef.org/resources/remote-learning-reachability-factsheet/, accessed 24 February 2021).

21. Phillips DE, Bhutta ZA, Binagwaho A, Boerma T, Freeman MC, Hirschhorn LR, et al. Learning from exemplars in global health: a road map for mitigating indirect effects of COVID-19 on maternal and child health. BMJ Glob Health. 2020 Jul;5(7):e003430. https://doi.org/10.1136/bmjgh-2020-003430 PMID:32737028

22. Cash R, Patel V. Has COVID-19 subverted global health?. Lancet. 2020 May 30;395(10238):1687-8. https://doi.org/10.1016/So1406736(20)31089-8. PMID:32539939

23. Pakistan: preparedness \& response plan COVID-19. Government of Pakistan. (https://reliefweb.int/sites/reliefweb.int/files/resources/PAKISTAN-Preparedness-and-Response-Plan-PPRP-COVID-19.pdf, accessed 24 February 2021). 